Tropical Journal of Pharmaceutical Research April 2017; 16 (4): 931-937

ISSN: $1596-5996$ (print); 1596-9827 (electronic)

(C) Pharmacotherapy Group, Faculty of Pharmacy, University of Benin, Benin City, 300001 Nigeria.

All rights reserved.

Available online at http://www.tjpr.org

Original Research Article

http://dx.doi.org/10.4314/tjpr.v16i4.27

\title{
Impact of duration of therapy on side effect profile of anti- HCV protocol: A retrospective cohort study from two tertiary health facilities in Pakistan
}

\author{
Zikria Saleem $^{1^{\star}}$, Hamid Saeed ${ }^{1}$, Furqan K Hashmi ${ }^{1}$, Nouman Saleem ${ }^{1}$, Uzma \\ Zafar $^{1}$, Maham Farrukh ${ }^{1}$, Aina Salah ${ }^{1}$, Saliha Ilyas ${ }^{1}$, Sehrish Shafique ${ }^{1}$, Mahrukh \\ Ahsan $^{1}$, Zeeshan Danish ${ }^{2}$ and Muhammad Islam ${ }^{3}$ \\ ${ }^{1}$ Department of Clinical Pharmacy, ${ }^{2}$ Department of Pharmaceutics, ${ }^{3}$ Department of Pharmaceutical Chemistry, Punjab \\ University College of Pharmacy, University of the Punjab, Allama lqbal Campus, 54000, Lahore, Pakistan
}

*For correspondence: Email: zikria.pharmacy@pu.edu.pk; Tel: +92322-9801981; Fax: +92-42-99211624

\begin{abstract}
Purpose: To evaluate the plausible risks and adverse effects related to the duration of therapy in hepatitis $C(\mathrm{HCV})$ patients in Lahore, Pakistan.

Method: A retrospective observational study involving $250 \mathrm{HCV}$ patients who received combination therapy with ribavirin and interferon was conducted. The patients were segregated into two groups on the basis of duration of therapy ( $\leq$ months and $>6$ months). Adverse effect profiles of patients under treatment were collected using a pre-validated questionnaire and compared using Pearson's ChiSquare Test/Chi-Square Goodness-of-Fit tests and unpaired t-test.

Results: Patients who underwent treatment for $\leq 6$ months frequently encountered side-effects such as GIT disturbance (23.77\%) and joint pains (29.63\%). Additionally, diabetes mellitus $(27.86 \%)$ and frequent injections (74.59\%) were the most commonly observed co-morbid condition and disease risk, respectively. On the other hand, in patients who underwent therapy for $>6$ months, skin disorders $(30.46 \%)$ and gastric acidity (10.15\%) were the most frequently observed side-effects with less frequent reporting on co-morbid conditions and disease risk factors. Moreover, there was a significant reduction in body weight $(p=0.03)$, serum bilirubin $(p=0.0005)$, albumin $(p=0.003)$ and triglycerides $(p$ $=0.006$ ) levels due to longer duration of treatment.

Conclusion: The data suggest that treatment-related risks are higher among HCV patients on shorter treatment duration whereas adverse events subside in patients on longer duration of therapy ( $>6$ months). Changes in biochemical profile were also more evident in those receiving treatment for periods $>6$ months.
\end{abstract}

Keywords: Interferon, Ribavirin, Side effects, Duration of therapy, Outcomes of therapy

Tropical Journal of Pharmaceutical Research is indexed by Science Citation Index (SciSearch), Scopus, International Pharmaceutical Abstract, Chemical Abstracts, Embase, Index Copernicus, EBSCO, African Index Medicus, JournalSeek, Journal Citation Reports/Science Edition, Directory of Open Access Journals (DOAJ), African Journal Online, Bioline International, Open-J-Gate and Pharmacy Abstracts

\section{INTRODUCTION}

Hepatitis $C$ is an infectious affliction that affects the functioning of hepatocyte owing to the hepatitis $\mathrm{C}$ virus (HCV), which can lead to life threatening pathological conditions such as cirrhosis, Hepato-cellular carcinoma and ultimately liver failure. HCV belongs to Flaviviridae family and is affecting over 170 million people worldwide [1]. The exact mechanism of infection is still to be elucidated as HCV has different genotypes with varied responses towards antiviral therapy based on 
HCV RNA load that is usually detected via polymerized chain reaction (PCR) [2]. Currently, no vaccine is available in the market for hepatitis C prophylaxis [3]. A standard combination therapy has been developed over a period of time for the treatment of $\mathrm{HCV}$, constituting Interferon injection and oral ribavirin [4].

The clinical objective of $\mathrm{HCV}$ treatment is to attain SVR for eradication of HCV-RNA with 6 months of interferon (IFN) therapy [5]. However, interferon therapy causes numerous side-effects such as thyroid dysfunction, visual and auditory impairment, renal hypo-perfusion, cardiac problems, anemia and pulmonary fibrosis [6]. Although some of these side effects require reduction in dose while others require complete discontinuation of therapy [7].

It is evident from the literature that interferon mono-therapy leads to side-effects as retinopathy, however the chances of such sideeffects become feeble when IFN is used in combination with anti-retroviral drugs as Ribavirin [8]. Some of the notable side effects include flu like symptoms, fever, chills, headache and myalgia along with leucopenia. Gastrointestinal related side-effects such as nausea, vomiting and diarrhea and even elevation of alanine aminotransferase levels are reported to be quite commonly encountered during the therapy [7]. Moreover, certain risks, such as alcohol intake and smoking can further aggravate the side effect profiles related to Interferon therapy and may compromise the clinical efficacy of these agents in HCV patients [9]. Higher doses of Interferon without checking the indicator levels in serum pose various adverse effects, which can be life threatening. Moreover, in the presence of risk factors, even the therapeutic dose of Interferon therapy can lead to many side effects requiring dose adjustment or discontinuation of therapy.

The present study was conducted in two tertiary health care facilities to evaluate the anti-HCV therapy related side-effects, co-morbid conditions and risks in HCV patients of Pakistan with regards to therapy duration.

\section{METHODS}

\section{Study design}

A retrospective observational study was designed to evaluate the risks and side effects related to therapy duration in $250 \mathrm{HCV}$ diagnosed patients in Lahore. The patients were segregated into two arms, namely less than six months and greater than six months, based on the duration of treatment.

\section{Study population and setting}

A total of 250 patients were selected as per defined inclusion and exclusion criteria of the study from out-patient departments of two teaching hospitals in Lahore, namely Mayo Hospital and Jinnah Hospital of Lahore, Pakistan.

\section{Inclusion criteria}

All HCV patients, irrespective of age, gender, ethnicity, education and socio-economic status, undergoing concurrent interferon and ribavirin therapy for $\mathrm{HCV}$.

\section{Exclusion criteria}

All patients either on Interferon or Ribavirin monotherapy were excluded from the study. Similarly, patients with more than 2 comorbidities were also not considered for the study.

\section{Study instrument}

A 70-item instrument was designed to document patients' demographics, medication history, disease history, co-morbidities, risk factors, therapy complications, side effects, and laboratory values retrospectively from the patient records. The questionnaire was validated by two researchers in the group by content and face validation methods. A team of trained data collectors facilitated the process of data collection from the two study settings. The questionnaire consisted of 9 portions, such as demographics, family and medication history, disease history, co-morbidities associated with hepatitis $\mathrm{C}$, risk factors, therapy complications, side effects of therapy and laboratory values.

\section{Data analysis}

Data was analyzed using Statistical Package for Social Sciences (SPSS) version $21^{\circledR}$ (IBM 2013) and Pearson's Chi-Square Test/Chi-Square Goodness-of-Fit was applied to compare different parameters of two groups based on the duration of therapy. This gives the OR (odd ratio) and $p$-values of different parameters.

\section{Ethical approval}

Approval for the study (no. ECCR/UCP/08/2015) was obtained from the Ethical Committee on Human Research, Punjab University College of 
Pharmacy, University of the Punjab, Lahore. The study was also approved by Review Board on Clinical Research Ethics of Mayo and Jinnah Hospitals. All the procedures were in accordance with the principles of the Declaration of Helsinki 1975 and its ensuing amendments [10].

\section{RESULTS}

\section{Patient demographics}

Patient's basic demographics are summarized in Table-1.Subjects comprised $57.2 \%$ of women and $42.8 \%$ men. About $52.4 \%$ of patients ranged between $25-44$ years of age (Table 1 ). Moreover, $91.2 \%$ enrolled HCV patients were married out of which $52.4 \%$ were housewives (Table 1).

\section{Risk factors and co-morbidities}

Potential risks and reported complications among the population in both the arms are summarized in Table 2. Notable risks with higher frequencies among patients with therapy duration of less or equal to six months include, injection $(\leq 6$ months; $74.59 \%$, > 6 months; $69.76 \%, p=$ 0.032), diabetes ( $\leq 6$ months; $27.86 \%,>6$ months; $17.18 \%, p=0.043)$ and liver related diseases ( $\leq 6$ months; $14.75 \%$, > 6 months; 6.25 $\%, p=0.028$ ) (Table 2). The risks and complications that were frequently higher in HCV patients with therapy duration of more than 6 months include, family link ( $\leq 6$ months; $14.75 \%$, $>6$ months; $22.65 \%, p=0.041)$ and blood transfusion ( $\leq 6$ months; $41.4 \%$, > 6 months; $32.78 \%, p=0.027$ ) (Table 2).

Table 1: Patient's basic demographics

\begin{tabular}{|c|c|c|c|}
\hline \multirow[t]{2}{*}{ Parameter } & \multicolumn{2}{|c|}{ Duration of therapy } & \multirow{2}{*}{$\begin{array}{c}\text { Total } \\
(n=250)\end{array}$} \\
\hline & $\begin{array}{c}\leq 6 \text { months } \\
(n=122)\end{array}$ & $\begin{array}{c}>6 \text { months } \\
(n=128)\end{array}$ & \\
\hline \multicolumn{4}{|l|}{ Age } \\
\hline $18-24$ & $6(4.91)$ & $1(0.78)$ & $7(2.8)$ \\
\hline $25-44$ & $59(48.36)$ & $72(56.25)$ & $131(52.4)$ \\
\hline $45-64$ & 55 (45.08) & $51(39.84)$ & $106(42.4)$ \\
\hline$>65$ & $2(1.63)$ & $4(3.12)$ & $6(2.4)$ \\
\hline \multicolumn{4}{|l|}{ Gender } \\
\hline Male & 57 (53.27) & 50 (39.06) & $107(42.8)$ \\
\hline Female & 65 (53.27) & 78 (60.93) & $143(57.2)$ \\
\hline \multicolumn{4}{|l|}{ Ethnic group } \\
\hline Punjabi & $104(85.24)$ & $111(86.71)$ & $215(86)$ \\
\hline Pathan & $9(7.3)$ & $5(3.90)$ & $14(5.6)$ \\
\hline Sindhi & $1(0.81)$ & 0 & $1(0.4)$ \\
\hline Others & $8(6.55)$ & $12(9.37)$ & $20(8)$ \\
\hline \multicolumn{4}{|c|}{ Residential area } \\
\hline Rural & $56(45.90)$ & 55 (42.96) & $111(44.4)$ \\
\hline Urban & 66 (54.09) & 73 (57.03) & $139(55.6)$ \\
\hline \multicolumn{4}{|c|}{ Educational level } \\
\hline Higher & $7(5.73)$ & $2(1.56)$ & $9(3.6)$ \\
\hline Secondary & $17(13.93)$ & $15(11.71)$ & $32(12.8)$ \\
\hline Middle & 19 (15.57) & $9(7.03)$ & $28(11.2)$ \\
\hline Primary & $46(37.70)$ & $29(22.65)$ & $75(30)$ \\
\hline Illiterate & $33(27.04)$ & $73(57.03)$ & $106(42.4)$ \\
\hline \multicolumn{4}{|l|}{ Marital status } \\
\hline Married & $108(88.5)$ & $120(93.75)$ & $228(91.2)$ \\
\hline Single & $12(9.83)$ & $5(4.09)$ & $17(6.8)$ \\
\hline Widow & $2(1.63)$ & $3(2.45)$ & $5(2)$ \\
\hline \multicolumn{4}{|l|}{ Occupation } \\
\hline Housewife & $58(47.54)$ & 73 (57.03) & $131(52.4)$ \\
\hline Labor & 14 (11.47) & $18(14.06)$ & $32(12.8)$ \\
\hline Unemployed & $12(9.83)$ & $7(6.56)$ & $19(7.6)$ \\
\hline Others & 38 (31.14) & 30 (23.43) & $68(27.2)$ \\
\hline \multicolumn{4}{|c|}{ Source of medicine } \\
\hline DHQ hospital & $41(33.60)$ & 34 (26.56) & $75(30)$ \\
\hline Hospital & $16(13.11)$ & $13(10.15)$ & $29(11.6)$ \\
\hline Medical store & 41 (33.60) & $62(48.43)$ & $103(41.2)$ \\
\hline Pharmacy & $3(2.45)$ & $2(1.56)$ & $5(2)$ \\
\hline Others & $21(17.21)$ & 17 (13.28) & $38(15.2)$ \\
\hline
\end{tabular}


Side effect profiles among HCV patients on anti-HCV combination therapy

Table 3 illustrates the side effect profiles and clinical presentation of enrolled HCV patients. Noteworthy clinical features among HCV patients in both the arms include, respiratory tract infection ( $\leq 6$ months; $30.32 \%$, > 6 months; 53.9 $\%, p=0.0005$ ), skin disorder ( $\leq 6$ months; 19.67 $\%$, > 6months; $30.46 \%, p=0.049)$ and cough ( $\leq$
6 months; $4.09 \%,>6$ months; $0.78 \%, p=$ 0.047 ) (Table 3). Moreover, the most frequently reported side effects were bleeding disorders $(\leq$ 6 months; $52.45 \%$, > 6 months; $52.34 \%$ ), vomiting ( $\leq 6$ months; $38.52 \%$, > 6 months; $42.18 \%$ ), joint disorders ( $\leq 6$ months; $29.63 \%$, > 6 months; $23.75 \%, p=0.029$ ), headache ( $\leq 6$ months; $25.40 \%$, > 6 months; $33.59 \%)$ and insomnia ( 6 months; $19.6 \%$, > 6 months; 25.78 $\%)$.

Table 2: Risk factors and co-morbidities among the enrolled patients

\begin{tabular}{|c|c|c|c|c|}
\hline \multirow[t]{2}{*}{ Parameter } & \multicolumn{2}{|c|}{ Duration of therapy } & \multirow[b]{2}{*}{$\begin{array}{c}\text { Total } \\
(n=250)\end{array}$} & \multirow[b]{2}{*}{$\begin{array}{l}x^{2} \text {-Test }{ }^{\dagger} \\
\text { (p-value) }\end{array}$} \\
\hline & $\begin{array}{c}\leq 6 \text { months } \\
(n=122)\end{array}$ & $\begin{array}{c}>\text { months } \\
(n=128)\end{array}$ & & \\
\hline Smoking & $34(27.86)$ & $32(25)$ & $66(26.4)$ & 0.84 \\
\hline Family history & $18(14.75)$ & $29(22.65)$ & $47(18.8)$ & $0.041^{*}$ \\
\hline Pregnancy & $5(4.09)$ & $1(0.78)$ & $6(2.4)$ & $0.039^{*}$ \\
\hline Dengue fever & $15(12.29)$ & $15(11.71)$ & $30(12)$ & 0.97 \\
\hline Blood transfusion & $40(32.78)$ & $53(41.40)$ & $93(37.2)$ & $0.027^{*}$ \\
\hline Hemodialysis & $0(0)$ & $2(1.56)$ & $2(0.8)$ & 0.071 \\
\hline Injection & $91(74.59)$ & $87(67.96)$ & $178(71.2)$ & $0.032^{*}$ \\
\hline Contact with infected person & $23(18.85)$ & $22(17.18)$ & $45(18)$ & 0.199 \\
\hline Shaving outside & $26(21.31)$ & $23(17.96)$ & 49 (19.6) & 0.062 \\
\hline Diabetes mellitus & $34(27.86)$ & $22(17.18)$ & $56(22.4)$ & $0.043^{*}$ \\
\hline Hypertension & 27 (22.13) & $30(23.43)$ & 57 (22.8) & 0.806 \\
\hline Other liver diseases & $18(14.75)$ & $8(6.25)$ & $26(10.4)$ & $0.028^{*}$ \\
\hline
\end{tabular}

Table 3: Clinical presentation and side-effect profiles

\begin{tabular}{|c|c|c|c|c|}
\hline \multirow[t]{2}{*}{ Clinical characteristics } & \multicolumn{2}{|c|}{ Duration of therapy } & \multirow[b]{2}{*}{$\begin{array}{c}\text { Total } \\
(n=250)\end{array}$} & \multirow[b]{2}{*}{$\begin{array}{l}X^{2} \text {-Test }{ }^{\dagger} \\
\text { (p-value) }\end{array}$} \\
\hline & $\begin{array}{c}\leq 6 \text { months } \\
(n=122)\end{array}$ & $\begin{array}{c}>6 \text { months } \\
(n=128)\end{array}$ & & \\
\hline Abdominal pain & $58(47.54)$ & $72(56.25)$ & $130(51.58)$ & 0.168 \\
\hline Fever & $96(78.68)$ & $97(75.78)$ & $193(77.2)$ & 0.584 \\
\hline Genitourinary symptoms & $4(3.27)$ & $8(6.25)$ & $12(4.8)$ & 0.272 \\
\hline Muscular pain & $61(50)$ & $70(54.68)$ & $131(52.4)$ & 0.458 \\
\hline Respiratory tract infection & $37(30.32)$ & $69(53.90)$ & $106(42.4)$ & $0.0005^{\star *}$ \\
\hline Hepatic encephalopathy & $46(37.70)$ & 38 (29.68) & $84(33.6)$ & 0.18 \\
\hline Ascites & $15(12.29)$ & $10(7.8)$ & $25(10)$ & 0.238 \\
\hline Cough & $5(4.09)$ & $1(0.78)$ & $6(2.4)$ & $0.047^{*}$ \\
\hline \multicolumn{5}{|l|}{ Side Effects } \\
\hline Vomiting & $47(38.52)$ & $54(42.18)$ & $101(40.4)$ & 0.24 \\
\hline Eye disorder & $34(27.86)$ & $26(20.31)$ & $60(24)$ & 0.149 \\
\hline Skin disorders & 24 (19.67) & $39(30.46)$ & $63(25.2)$ & $0.049^{*}$ \\
\hline Joint disorder & 36 (29.63) & $31(23.75)$ & 67 (26.8) & $0.029^{*}$ \\
\hline Headache & $31(25.40)$ & 43 (33.59) & 74 (29.6) & 0.06 \\
\hline Insomnia & 24 (19.67) & $33(25.78)$ & 57 (22.8) & 0.06 \\
\hline Irritability & $13(10.65)$ & $4(3.12)$ & $17(6.8)$ & 0.06 \\
\hline Acidity & $2(1.63)$ & $13(10.15)$ & $15(6)$ & $0.002^{* *}$ \\
\hline Loss of appetite & 17 (13.93) & 17 (13.28) & 34 (13.6) & 0.849 \\
\hline GIT disturbances & $29(23.77)$ & 14 (10.93) & $43(17.2)$ & $0.002^{* *}$ \\
\hline Bleeding disorder & $64(52.45)$ & 67 (52.34) & $131(52.4)$ & 0.642 \\
\hline Minor bleeding & 47 (38.52) & $54(42.18)$ & $101(40.4)$ & 0.643 \\
\hline Major bleeding & $17(13.92)$ & $15(11.71)$ & $31(12.8)$ & 0.493 \\
\hline Nasal bleeding & $3(2.45)$ & $4(3.12)$ & $7(2.8)$ & 0.949 \\
\hline Rectal bleeding & $8(6.55)$ & $7(5.46)$ & $15(6)$ & 0.549 \\
\hline
\end{tabular}


Table 4: Laboratory findings for the patients

\begin{tabular}{|c|c|c|c|c|}
\hline \multirow[t]{2}{*}{ Parameter } & \multicolumn{2}{|c|}{ Duration of therapy } & \multirow[b]{2}{*}{$\begin{array}{c}\text { Mean }^{*} \\
\text { Difference }\end{array}$} & \multirow[b]{2}{*}{$\begin{array}{c}\text { T-test }^{\dagger} \\
(p \text {-value })\end{array}$} \\
\hline & $\begin{array}{c}\leq 6 \text { months } \\
(n=122)\end{array}$ & $\begin{array}{c}>6 \text { months } \\
(n=128)\end{array}$ & & \\
\hline Weight $(\mathrm{kg})$ & $66.35 \pm 19.24$ & $61.08 \pm 16.35$ & 5.27399 & $0.03^{*}$ \\
\hline Serum ALT (IU/L) & $60.48 \pm 30.31$ & $61.14 \pm 37.07$ & -0.66715 & 0.159 \\
\hline Serum AST (IU/L) & $42.08 \pm 33.01$ & $45.72 \pm 33$ & -3.63369 & 0.24 \\
\hline Bilirubin (mg/dL) & $1.53 \pm 1.21$ & $0.92 \pm 0.85$ & 0.60457 & $0.0005^{\star *}$ \\
\hline $\begin{array}{l}\text { Alkaline } \\
\text { phosphatase (IU/L) }\end{array}$ & $236.87 \pm 103.15$ & $208.4 \pm 58.15$ & 28.47562 & 0.135 \\
\hline HB level (g/dL) & $11.24 \pm 1.99$ & $10.98 \pm 2.18$ & 0.26444 & 0.592 \\
\hline Albumin (g/dL) & $6.16 \pm 10.14$ & $3.47 \pm 0.82$ & 2.68501 & $0.003^{\star \star}$ \\
\hline $\begin{array}{l}\text { Prothrombin Time } \\
\text { (min) }\end{array}$ & $9.27 \pm 2.95$ & $10.07 \pm 3.38$ & -0.80272 & 0.359 \\
\hline Platelets $\left(10^{3} / \mathrm{uL}\right)$ & $206.820 \pm 107.244$ & $211.170 \pm 117.284$ & -4.3512 & 0.147 \\
\hline $\begin{array}{l}\text { Leukocytes } \\
\text { (no./uL) }\end{array}$ & $13482 \pm 87798.74$ & $5528.5 \pm 16110.37$ & 7953.2843 & 0.433 \\
\hline $\begin{array}{l}\text { Cholesterol } \\
\text { (mg/dL) }\end{array}$ & $138.11 \pm 26.19$ & $136.21 \pm 14.27$ & 1.89881 & 0.304 \\
\hline $\begin{array}{l}\text { Triglycerides } \\
(\mathrm{mg} / \mathrm{dL})\end{array}$ & $147.53 \pm 43.79$ & $121.65 \pm 29.52$ & 25.87247 & $0.006^{*}$ \\
\hline HCV RNA (IU/ml) & $90735 \pm 123207$ & $73939 \pm 185206$ & 16796.874 & 0.115 \\
\hline
\end{tabular}

\section{Laboratory findings}

Clinical lab values of the patients enrolled in both the arms are summarized in (Table 4). As shown in Table 4. No significant differences were observed in both the arms for majority of the lab values except for bilirubin ( $\leq 6$ months; $1.53 \pm$ $1.21,>6$ months; $0.92 \pm 0.85, p=0.0005)$, albumin ( $\leq 6$ months; $6.16 \pm 10.14,>6$ months; $3.47 \pm 0.82 p=0.003)$ and triglycerides $(\leq 6$ months; $147.53 \pm 43.79,>6$ months; $121.65 \pm$ 29.52, $p=0.006)$.

\section{DISCUSSION}

The incidences of HCV are seen to be more in urban societies and in particular in illiterate people due to lack of knowledge about the associated risks with re-use of needles and other such articles [14]. Studies have shown that majority of the side effects associated with Interferon therapy subside on therapy withdrawal and less likely to recur on initiating the therapy with a lower dose [15]. Combination therapy of Interferon and Ribavirin is also associated with numerous predictable side-effects. The unpredictable side effects were usually caused due to age, gender, duration of therapy and comorbidities [16]. Moreover, the occurrence of some of the side-effects has been attributed to long term therapy with Interferon and Ribavirin, requiring either dose reduction or discontinuation of therapy.
Literature evidences suggest that duration of anti-HCV therapy coupled with higher Interferon doses can cause various side effects, most of them unpredictable [17]. Our data suggested that some of the side effects such as headache, insomnia, gastric acidity, vomiting and bleeding were more pronounced in patients with anti-HCV treatment duration for more than six months, whereas the other group showed fewer. However, the side-effects that subsided with the passage of time were joint pains, optical disorder (retinopathy), muscle problems (muscular pain), autoimmune disorders (arthritis), CNS problems (headache, insomnia), abdominal pain, respiratory problems (difficult breathing) and hematological problems (anemia, bleeding).

Furthermore, our findings are in agreement with previous reports [7] that have suggested that some of the side-effects like anemia, fever, headache, respiratory problems (difficulty in breathing), muscular problems and skin problems might exacerbate after 6 months of therapy, which leads to dose reduction or therapy withdrawal. Our data further suggested that anemia worsened with increasing therapy duration of more than 6 months, consistent with previous reports anemia being most common side-effect of Interferon and Ribavirin therapy possibly due to direct toxic effects of ribavirin on RBCs promoting hemolysis [18]. Studies have also shown that Interferon therapy in HCV patients with hypertension can induce or aggravate retinopathy possibly due to narrowing 
of arteries affecting retinal microcirculation [19]. Interferon therapy can also induce skin, CVS and musculoskeletal side effects [20] and can precipitate or perpetrate pathological events favoring autoimmune diseases [21]. Along with side-effects, numerous therapy and patientrelated risks can compromise the clinical efficacy of interferon therapy and further aggravate the disease condition. The risk factors that are believed to complicate interferon therapy include smoking, alcohol, blood transfusion and use of non-sterilized personal hygiene products as razor blades for shaving.

Our data also suggested that effectiveness of Interferon therapy was reduced in smokers and in individuals with co-morbidities such as diabetes mellitus and hypertension. Similar results have been reported previously, suggesting that these risk factors can prolong therapy duration which may result in serious side effects [22]. Smoking increases the chances of fibrosis and damage to the liver in patients with chronic hepatitis C [23]. Another study suggested that Type 2 diabetes is more common in patients with HCV infection [24]. Therefore, all these side effects and risk factors not only resulted in reduced therapy responses but also favored prolonged treatment further complicating disease and side-effect management.

\section{Study limitations}

The present study has some limitations. We were unable to ensure random sampling; no standard criteria was used for documenting side effect profiles; and we were unable to associate the impact of disease duration with therapy duration and reported risks and complications. Moreover, the study was carried out in only two healthcare settings, therefore warranting a larger scale of study.

\section{CONCLUSION}

The combination of interferon and ribavirin for the treatment of hepatitis $\mathrm{C}$ was associated with several side effects which could be aggravated by concomitant exposure to risk factors, such as smoking, blood transfusion, use of non-sterile tools for surgical and medical procedures. Besides concomitant disease risks, diabetes and hypertension might favor therapy-related side effects and could hinder optimal therapeutic response. Seemingly, the presence of either disease risks or co-morbidities may further exacerbate the side-effects, possibly by prolonging therapy duration and compromising clinical efficacy of anti-HCV. The data suggest that treatment-related risks are higher in the first group of patients whereas adverse events are lower in patients on longer duration of therapy (>6 months). However, Changes in biochemical profiles of patients were also more pronounced in patients on longer duration of therapy.

\section{DECLARATIONS}

\section{Acknowledgement}

The authors acknowledge the staff of Mayo Hospital, Jinnah Hospital and University of the Punjab Lahore, Pakistan authorities for their assistance in conducting this study.

\section{Conflict of Interest}

No conflict of interest associated with this work.

\section{Contribution of Authors}

The authors declare that this work was done by the authors named in this article and all liabilities pertaining to claims relating to the content of this article will be borne by them.

\section{Open Access}

This is an Open Access article that uses a funding model which does not charge readers or their institutions for access and distributed under the terms of the Creative Commons Attribution License (http://creativecommons.org/licenses/by/ 4.0) and the Budapest Open Access Initiative (http://www.budapestopenaccessinitiative.org/rea d), which permit unrestricted use, distribution, and reproduction in any medium, provided the original work is properly credited.

\section{REFERENCES}

1. Kim Al, Saab S. Treatment of hepatitis C. Am J Med. 2005; 118(8): 808-815.

2. Ohno O, Mizokami M, Wu RR, Saleh MG, Ohba Kl, Orito $E$, Mukaide M, Williams $R$, Lau JY. New hepatitis $C$ virus (HCV) genotyping system that allows for identification of HCV genotypes $1 a, 1 b, 2 a, 2 b, 3 a, 3 b, 4,5 a$, and $6 a . J$ Clin Microbiol. 1997; 35(1): 201-207.

3. Shepard CW, Finelli L, Alter MJ. Global epidemiology of hepatitis $C$ virus infection. Lancet Infect Dis, 2005; 5(9): 558-567.

4. Di Bisceglie AM, Shindo M, Fong TL, Fried MW, Swain MG, Bergasa NV, Axiotis CA, Waggoner JG, Park $Y$, Hoofnagle $\mathrm{JH}$. A pilot study of Ribavirin therapy for chronic hepatitis C. Hepatology, 1992; 16(3): 649-654.

5. Manns MP, McHutchison JG, Gordon SC, Rustgi VK, Shiffman $M$, Reindollar $R$, Goodman ZD, Koury $K$, Ling $\mathrm{MH}$, Albrecht JK, Group IH. Peg-Interferon alfa-2b plus Ribavirin compared with Interferon alfa-2b plus Ribavirin 
for initial treatment of chronic hepatitis $C$ : A randomised trial. Lancet Gastroenterol Hepatol, 2001; 358(9286): 958-965.

6. Dusheiko G. Side effects of a Interferon in chronic hepatitis C. Hepatology, 1997; 26(S3): 112S-121S.

7. Fried MW. Side effects of therapy of hepatitis $C$ and their management. Hepatology, 2002; 36(S1): S237-S244.

8. Jain K, Lam WC, Waheeb S, Thai Q, Heathcote J. Retinopathy in chronic hepatitis $C$ patients during Interferon treatment with Ribavirin. $\mathrm{Br} J$ Ophthalmol, 2001; 85(10): 1171-1173.

9. Bellentani S, Pozzato G, Saccoccio G, Crovatto M, Croce LS, Mazzoran L, Masutti F, Cristianini G, Tiribelli C. Clinical course and risk factors of hepatitis $C$ virus related liver disease in the general population: report from the Dionysos study. Gut, 1999; 44(6): 874-880.

10. Association WM. World Medical Association Declaration of Helsinki: Ethical principles for medical research involving human subjects. JAMA. 2013; 310 (20): 2191 2194.

11. Alter MJ. Epidemiology of hepatitis C. Hepatology, 1997; 26(S3): 62S-65S.

12. Lavanchy $D$. Evolving epidemiology of hepatitis $C$ virus. Clin Microbiol Infect, 2011; 17(2): 107-115.

13. Wasley A, Alter MJ. Epidemiology of hepatitis C: geographic differences and temporal trends. In Seminars in liver disease Hepatitis C: State of the Art at the Millennium, 2000. 20(1): 18-21.

14. Aust J. Sharing of drug preparation equipment as a risk factor for hepatitis C. Commun Dis Public Health.2000; 3:121-6.

15. Smedley H, Katrak M, Sikora K, Wheeler T. Neurological effects of recombinant human Interferon. .BMJ Open Diabetes Res Care, 1983; 286(6361): 262-264.
16. Qurishi N, Kreuzberg C, Lüchters G, Effenberger W, Kupfer B, Sauerbruch T, Rockstroh JK, Spengler U. Effect of antiretroviral therapy on liver-related mortality in patients with HIV and hepatitis $C$ virus coinfection. Lancet 362(9397), 1708-1713.

17. Okanoue $T$, Sakamoto $S$, Itoh $Y$, Minami M, Yasui $K$, Sakamoto M, Nishioji K, Katagishi T, Nakagawa Y, Tada $H$, Sawa $Y$. Side effects of high-dose Interferon therapy for chronic hepatitis C. J Hepatol 1996; 25(3): 283-291.

18. Kowdley KV. Hematologic side effects of Interferon and Ribavirin therapy. Clin J Gastroenterol, 2005; 39:S3-S8.

19. Okuse C, Yotsuyanagi $H$, Nagase $Y$, Kobayashi $Y$, Yasuda K, Koike $K$, lino S, Suzuki M, Itoh F. Risk factors for retinopathy associated with Interferon alpha-2b and Ribavirin combination therapy in patients with chronic hepatitis C. World J Gastroenterol, 2006; 12(23): 3756.

20. Hayasaka S, Nagaki $Y$, Matsumoto M, Sato S. Interferon associated retinopathy. $\mathrm{Br} J$ Ophthalmol, 1998; 82(3): 323-325.

21. Wilson LE, Widman D, Dikman SH, Gorevic PD. Autoimmune disease complicating antiviral therapy for hepatitis $C$ virus infection. In: Seminars in arthritis and rheumatism. Elsevier, 2002; (3): 163-173.

22. El-Zayadi A, Hamdy H, El-Tawil A, Badran H, Attia M, Saeed A. Impact of cigarette smoking on response to Interferon therapy in chronic hepatitis C Egyptian patients. World J Gastroenterol, 2004; 10(20): 29632966.

23. ElZayadi AR. Heavy smoking and liver. World $J$ Gastroenterol, 2006; 12(38): 6098.

24. Mehta SH, Brancati FL, Sulkowski MS, Strathdee SA, Szklo M, Thomas DL. Prevalence of type 2 diabetes mellitus among persons with hepatitis $C$ virus infection in the United States. Ann Intern Med, 2000; 133(8): 592599 